\title{
Effectiveness of Comic Based Learning in Pancasila and Civic Education in Inclusive School
}

\author{
Totok Suyanto ${ }^{1}$, Ari Wahyudi ${ }^{2}$, Bambang Sigit Widodo ${ }^{3}$, Refti Handini Listyani ${ }^{4}$ \\ \{totoksuyanto@unesa.ac.id ${ }^{1}$, ariwahyudi@unesa.ac.id ${ }^{2}$, bambangsigit@unesa.ac.id ${ }^{3}$, \\ reftihandini@unesa.ac.id $\left.{ }^{4}\right\}$ \\ ${ }^{1}$ Department of Pancasila and Civic Education, Indonesia \\ ${ }^{2,4}$ Department of Sociology, Indonesia \\ ${ }^{3}$ Department of Geography Education, Indonesia
}

\begin{abstract}
This research aimed to examine children's learning boredom and their low interest in learning Pancasila and Civic Education subject. The researchers target is to create a breakthrough in learning through comic in the form of Pancasila and Civic Education material with simple stories and interesting images from children's daily real-life. This research was designed by using $\mathrm{R} \& \mathrm{D}$ through data collection techniques; questionnaire and test. The result of this research are (1) There is effectiveness in learning Pancasila and Civic Education by applying comic-based learning to children with learning difficulties in Mojokerto, (2) The production of this research was comic learning books for students in grade 3, 4 and 5 and registered on ISBN.
\end{abstract}

Keywords: Comic based learning, Affective domain, and Children learning difficulties

\section{Introduction}

Teachers' duty in the 21 st century has a very difficult challenge. The teacher is not only teaching in front of the class but simultaneously must play a role of the teacher nowadays. Teachers have to prepare the students to master 21 st century skills, namely: critical and analytical thinking, creative and innovative, communicative, and collaborative. In achieving this conditions, the teachers must play a role as (1) facilitator, teacher is able to help students in the learning process, (2) goalkeeper, teacher helps students to be able to filter negative influences, (3) educator, teacher is able to convey subjects to be understood by students, (4) catalysts, teacher is able to identify, explore and optimize the students' potential and (5) connector, teacher is able to connect students with diverse learning resources both inside and outside the school [1].

Educational conditions nowadays require the teachers playing a role as parents' representatives in formal education. It means that society and the state have given trust to teachers to educate children in the school. The essence of learning in school is not only to get the knowledge but also learn and interact with other students and the teachers. Child association will always be influenced 
by education association. These influences consciously absorb the example they have experienced and observed. This inspiration is based on the concept of education by Ki Hajar Dewantara, that in front of an education must set an example, in the midst of an educator must create initiatives and ideas, and behind an educator must provide encouragement and direction [2].

The problem faced by children with learning difficulties is the low interest in learning and quickly bored, especially facing Pancasila and Civic Education material which is full of storytelling habits. The result of data from Pusbang Kurrandik Balitbang Diknas's research show that 696 of 4994 students had learning difficulties or 13.9\% in percentage [7]. The fantastic amount to be handled intensively. Therefore through this research, it has found a breakthrough or solution towards one of children's difficulties in the material of Pancasila and Civic Education by providing comic-based learning packages. The underlying assumption is the fun learning by seeing pictures and understanding the contents of the story will encourage children's learning interest and reduce boredom. This assumption is getting stronger because of a finding show that mentally disabled children in Sidoarjo can reach the affective domain in learning Pancasila and Civic Education through plays such as puppet stage [8], snake ladder [9] and illustrated stories [10].

Research support stated that children with learning disabilities are fields of work that are still relatively young in the special education world, even these children belong to a separate group called learning disabilities. The prevalence of children with learning difficulties in schools according to some literature is $1-30 \%$ (Learner, 1981), 2 - 30\% (Lovitt, 1989), and is estimated to reach $15 \%$ of the population of elementary school children (Geddes, 1985). While the results of a survey of 25 elementary schools in DKI in 1994 found $16.52 \%$ of children had learning difficulties as stated by the teacher (Mulyono \& Ibrahim, 1994). Setiyatna (2003) conducted a study of the learning difficulties in MI in Sukoharjo district found that 470 of 1153 students had learning difficulties (40.76\%) [11].

The data shows that learning difficulties need a breakthrough to handle intensively. Murtadlo has tried to make efforts to improve the learning achievement of children with learning disabilities in Waru I and Waru IV elementary school through a cooperative approach using TAI type and the results are quite significant [12]. In addition, Hidayah tried to improve teachers' ability to deal with children with learning difficulties, the result shows that there are differences in children's learning achievement before and after the intervention of teachers who have the ability to handle children with learning difficulties [13].

As a reference theory for researchers to deal with child learning difficulties is an effort to identify children's learning difficulties. If the researchers believe that the main characteristics of learning difficulties are hyperactivity and perceptual motor problems, the identification procedure will be directed there; if it is language problems, then identification will be focused on measuring language skills. Thus identification of children with learning difficulties will depend on the definition, orientation and evaluation procedures used.

The breakthrough that must be given is how to make children who have learning difficulties learn and not easily become bored. In this study, the application of fun-based learning models in the form of comic was examined. From the previous study, it was found that plays have great advantages on children's development. Play is a learning experience that is very useful for children, for example, getting experience in building relationships with friends, increasing vocabulary, channeling depressed feelings. One of the best-loved games in childhood is the snakes 
and ladders, puppet stages, monopolies and illustrated stories. At the age of kindergarten to elementary school grade 3 , role play is often to do. In the role play, children imitate the activities of people they have encountered in everyday life. Children can also play an imaginative roles, play a character who is known through cartoons or fairy tales. For instance police and criminals, batman, act as a mother and so on. An excellent imaginative facilities for the low-grade kindergarten, elementary school or special school are games that can be communicated by them. In general, every child likes games that are in accordance with their age and level of intelligence. Therefore, this study focuses on: (1) is there effectiveness in applying the comic-based learning in Pancasila and Civic Education in inclusive schools? (2) how is the final product of comic-based learning in Pancasila and Civic Education?.

\section{Research Method}

This study is an experimental development research with pre-experimental design. Research \& development modifying Borg and Gall models [14] using five main steps: (1) analyze the product that will be developed, (2) develop the initial product, (3) experts' validation and revision, (4) small scale field trials and product revisions and (5) large-scale field trials and final products. The pre-experimental design was used to examine the effectiveness of the comic-based learning in Pancasila and Civic Education in inclusive schools. The design applied was one group pre-test post-test design then analyzed by statistical formula.

The study was conducted in Mojokerto district with the research target of Kauman Elementary School Mojosari Sub-District, Sawahan Elementary School in Bangsal Sub-District, Randubangu Elementary School in Pungging Sub-District and Modopuro Elementary School in Trawas SubDistrict. The sample of this study was children with learning difficulties at school which has high prevalence of learning difficulties (15-20\%) from the total number of the students and who were able to read (grade 3,4, and 5).

Data collections used in this study were observation, interview and test techniques. Observation and interview was used to collect data on the feasibility of comic-based learning, the researchers collect operational constraints and the opinion of team observers (comic experts, academics and class teachers) on the feasibility of comics to become a Pancasila and Civic Education learning model. Test was conducted to measure the effectiveness of the comic-based learning in Pancasila and Civic Education. Data analysis was used statistics Sign Test for small samples of the test results data before and after learning comics in each school.

\section{Results and Discussions}

The first result of the research was a prototype of comic-based learning for Pancasila and Civic Education subjects that was ready to be widely tested in 4 inclusive elementary schools in Mojokerto district. The second result is the experimental result of 4 inclusive school in Mojokerto district. The result of data analysis can be explained based on research problem (1) The effectiveness of comic in learning Pancasila and Civic Education can be described as follows: (a) 
Sawahan Elementary School showed that $\mathrm{z}>1.96$ and $\mathrm{z}<-1.92$, because $\mathrm{z}$ counts $2.83>$ from the critical value 1.96, it can be analyzed that there is effectiveness in achieving affective domain in learning Pancasila and Civic Education by applying comic-based learning to children with learning disability, (b) Sukosari Elementary School showed that $\mathrm{z}>1.96$ and $\mathrm{z}<-1.96$, because $\mathrm{z}$ counts $3.36>$ from the critical value 1.96, it can be analyzed that there is effectiveness in achieving affective domain in learning Pancasila and Civic Education by applying comic-based learning to children with learning disability, (c) Wonosari I Elementary School showed that $\mathrm{z}>$ 1.96 and $\mathrm{z}<-1.96$, because $\mathrm{z}$ counts $2.68>$ from the critical value 1.96 , it can be analyzed that there is effectiveness in achieving affective domain in learning Pancasila and Civic Education by applying comic-based learning to children with learning disability, (d) Bangsal Elementary School showed that $\mathrm{z}>1.96$ and $\mathrm{z}<-1.96$, because $\mathrm{z}$ counts $2.71>$ from the critical value 1.96 , it can be analyzed that there is effectiveness in achieving affective domain in learning Pancasila and Civic Education by applying comic-based learning to children with learning disability, (e) Trowulan Elementary School showed that $\mathrm{z}>1.96$ and $\mathrm{z}<-1.96$, because $\mathrm{z}$ counts $2.5>$ from the critical value 1.96, it can be analyzed that there is effectiveness in achieving affective domain in learning Pancasila and Civic Education by applying comic-based learning to children with learning disability. The overall result in Mojokerto district showed that $\mathrm{z}>1.96$ and $\mathrm{z}<-1.96$, because $\mathrm{z}$ counts $6.25>$ from the critical value 1.96 , so it can be analyzed that there is significant effectiveness in achieving affective domain in learning Pancasila and Civic Education by applying comic-based learning to children with learning disability in Mojokerto district, (2) The form of the final product of the comic-based learning in Pancasila and Civic Education is comic learning after going through improvements. The final form is comic books for grades 3, 4, and 5 which have registered ISBN.

The results of this study are in line with Sunaengsih's findings that the advantages of teaching media that attract students' attention and enhance learning motivation if it can be done by students in a real way in their learning environment. Children will do a lot of learning activities so they are not only listen to the teacher but also other activities [15].

Exemplary, initiative, and direction of an educator must be adjusted to the level of students' development. The critical attitude of elementary school children are just beginning to develop, so they imitate what they observe and witness from their friends and teachers. Those behavior shows that they are just learning how to live and behave. In fact, they have not really realized that their actions and speech is good or bad and right or wrong. Therefore they need to be guided about their manners and attitudes [3]. The role of the teacher to foster a polite and orderly manner only by explaining the lesson is not enough, they need to give examples and concrete actions of it. Description of words or verbalism will be less meaningful compared to the attitudes, examples and real actions. So teachers' personal inside and outside the class is the center of attention of students, role models, or their idol. Therefore, a teacher must behave in an exemplary manner.

Educational theory stated that students are not educational objects or teaching objects, but a subject whose personal potential consciously and actively involved in the teaching and learning process. The learning process is an auto activity or independent activity based on the curriculum as a runway towards the goal. The teachers should be realized that the conditions of the learning environment should be suitable and support the success of the teaching and learning process. In addition, the supporting condition is teacher's attitude to encourage and foster students' motivation and provide adequate learning media. These conditions will encourage students to actively learn 
by walking ahead to face and solve the learning problems, while the teacher walks behind tut wuri handayani [4].

To teach Pancasila and Civic Education (PPKn), teachers must identify themselves with the values and practices of moral principles, means that the teacher is always inspired and based on moral values. It is because Civic Education requires a lot of moral behavior or affective domain in the learning process. Therefore the teacher must be creative in finding methods and media that suitable with the conditions of the children's learning development. According to the contents of article 36 paragraph 3 of Act No. 20 of 2003, the curriculum is prepared in accordance with the level of education within the framework of the NKRI by paying attention in enhancing faith and taqwa; enhancing noble character; enhancing the potential, intelligence, and interests of students; the diversity of regional and environmental; the demands of regional and national development, the demands of the working world, the development of science, technology and art, religion, the dynamics of global development and national unity and national values [5].

The curriculum mandated in Act No. 20 of 2003 article 36 will not be realized by students in their daily lives if the teacher only explains or gives lectures the material, especially for children with learning difficulties, because this will make the child quickly bored and will antipathy towards the materials. Therefore, through this research, it is assumed that the attitudes demanded in Pancasila and Civic Education subjects will be effective to be learned by students, especially elementary school children, if there are any interesting media which was children's favorite, namely behavioral examples through comic. The comic needs to be created with an attractive design between the image and the content of the material. Therefore, comics can be a children's entertainment and able to teach children through the message content in it. Specifically to reduce elementary school children dependency on playing smartphone [6].

In addition, Saputro said that build students' characteristics depends on how the teacher manages learning by using the media. The findings of the study state that learning using comic media that can attract children's concentration, can form a positive character. The manifestation is human practical act, if they are doing their duty as well as possible, especially those that are related to devotion to fellow humans, then God will be with him. From that statement, normal and abnormal humans, disabled and non-disabled, men and women, young and old have the same rights and position in God. As well as children with learning difficulties, even though their abilities are lower than other normal humans, they have been provided their accountability according to their abilities. They need to be educated to respect and love their God by being introduced to all His glory, His patience and His mercy. This process of forming values, the role of teachers in the learning process is required to be creative in finding a way out to overcome students' boredom in learning, especially students with learning difficulties [16].

Wahyudi said on his research about comic-based learning model to reach the affective domain of Pancasila and Civic Education, that comic media whose storyline is filled with children's reallife in their everyday environments is more effective in building children's learning awareness. Children are invited to remember what has been done then poured into the story ideas which described in the true story and get a positive response for students. The teacher's role in this case only controls the children's learning behavior when playing and reading comics. In addition, it is clear that communicative media such as puppet shows, snake and ladders, illustrated story, monopoly games and comics can overcome students' boredom in the classroom especially for children with learning difficulties [17]. 
Lubis emphasized on the results of his study of the development of PBL-based comics to improve Pancasila and Civic Education learning outcomes, that comics became interesting and loved by children in the learning process when it converted to innovative learning models. The form of the learning model is designed through the Lesson Plan (RPP) model of solving children's problems enthusiastically to solve their problems through reading comics. They are happy and will looking for themselves by reading the comics which guided with a fun learning model [18].

\section{Conclusions and Suggestion}

The result of this research are (1) There is effectiveness in learning Civic Education by applying comic-based learning to children with learning difficulties in Mojokerto, (2) The production of this research was comic learning books for students in grade 3,4 and 5 and registered on ISBN.

Suggestions that can be given are (1) the teacher should improvise and innovate in all aspects, especially in learning media because it can encourage and arouse student learning enthusiasm, (2) no matter how great the media produced by the teacher, it still cannot replace the teacher's position in the process of maturing children, so the assistance in learning the teachers' roles are still needed, (3) children's imaginative during the development period are needed to accelerate the process of reasoning power. It is necessary to create and carry out adequate facilities by the Department of Education and Culture to accommodate the creation of the younger generation, (4) the demands for advancement in science and technology require all educational components to

participate in the mobilization of creative ideas at the spearhead level laying the foundations of education.

\section{Acknowledgements}

The authors wish to thank the Dean of FISH Unesa and the executives that have given the researchers the opportunity to participate and present this article in ICESI 2019 UNNES.

\section{References}

[1] S. R. Pantjastuti, "Milestone 100 tahun menuju generasi emas," 2019.

[2] H. A. R. Tilaar, Pendidikan, Kebudayaan, dan Masyarakat Madani Indonesia, Pertama. Bandung: Rosdakarya, 1999.

[3] M. Samani, Konsep dan Model Pendidikan Karakter, Pertama. Bandung: PT Remaja Rosdakarya, 2013.

[4] A. Widyawati and A. K. Prodjo Santoso, "Pengembangan media komik IPA untuk meningkatkan motivasi belajar dan karakter peserta didik SMP," Inov. Pendidik. IPA, vol. 1, no. Pendidikan, 2015.

[5] U. 20, Sistem Pendidikan Nasional. Bandung: Citra umbara, 2003. 
[6] R. Laila, "Pengembangan Kualitas Pembelajaran di Era Milenial," 2019, pp. 28-35.

[7] Sujarwanto, Perkembangan Anak Berkebutuhan Khusus, Edisi-1. Surabaya, 2014.

[8] A. Wahyudi, "Urgensi Panggung Boneka dalam Pembelajaran PPKn di SLB Tunagrahita,” J. Media Pendidik. dan Ilmu Pengetah., vol. XXII (4), no. Pendidikan, pp. 23-30, 1999.

[9] A. Wahyudi, "Penerapan Permainan Ular Tangga sebagai Media Simulasi untuk Mencapai Ranah Afektif dalam Pembelajaran PPKn di SLB Tunagrahita," Surabaya, 2003.

[10] A. Wahyudi, "Penerapan Teknologi Media Cerita Bergambar untuk Mencapai Ranah Afektif dalam Pembelajaran PPKn," Surabaya, 2004.

[11] S. Soemantri, Psikologi Anak Luar Biasa, Ke-1. Jakarta: Depdikbud, 2006.

[12] Murtadlo, "Peningkatan Prestasi Belajar Siswa Berkesulitan Belajar Membaca Menulis melalui Pendekatan Kooperatif Tipe TAI di SD,” J. Pendidik. Dasar, vol. 5 (1), no. Pendidikan, 2005.

[13] N. Hidayah, "Peningkatan Kemampuan Guru dalam Pembelajaran Anak Gangguan Gizi yang Mengalami Kesulitan Belajar di Sekolah Dasar," J. Rehabil. Remediasi, vol. 13 (1), no. Pendidikan, 2003.

[14] W. R. Borg and M. D. Gall, Educational Research: An Introduction. London: Longman.Inc, 2003.

[15] C. Sunaengsih, "Pengaruh Media Pembelajaran terhadap Mutu Pembelajaran di SD terakreditasi A," Sumedang, 2018.

[16] H. B. Saputo, "Pengembangan Media Komik Berbasis Pendidikan Karakter pada Pembelajaran Tematik Integratif Klas IV SD," J. Prima Edukatia, vol. 3 (1), no. Pendidikan, pp. 61-72, 2015.

[17] A. Wahyudi, "Model Pembelajaran Berbasis Komik untuk Mencapai Ranah Afektif pada PPKn bagi Anak Berkesulitan Belajar," J. Pendidik. dan Kebud., vol. 16 (1) Edi, no. Pendidikan Inklusi, pp. 43-52, 2010.

[18] M. A. Lubis, "Pengembangan komik berbasis model Problem Base Learning (PBL) untuk meningkatkan hasil belajar PKn siswa kleas V MIN Medan Sunggal,” J. Temat., vol. 8 (3), no. Pendidikan, pp. 238-244, 2018. 